\title{
Productivity in Mechanizing Early Tending in Spruce Seedling Stands
}

\author{
Johanna Routa, Yrjö Nuutinen, Antti Asikainen
}

\begin{abstract}
According to National Forest Inventory data, there is an urgent need for tending seedling stands of at least 700,000 ha and a need for 1 million ha in the next few years in Finland. The motivation for forest owners to conduct pre-commercial silvicultural operations is low due to the associated high costs. Especially the costs of tending and clearing operations after the regeneration of the stand have been increasing. In addition, the availability of labor is a restricting factor due to the high seasonality of silvicultural works.

In the 2000s, several solutions for the mechanization of tending have been proposed. These are based on the use of harvester or a forwarder as a base machine. Typically, light weight base machines are favored to reduce the hourly cost of operations and the impacts on the remaining seedlings. There have been challenges with the high speed of the cutting device, which increases the risk of damages to the head and the ignition of forest fires when the circular saw or chain hits stones, for example. In addition, the chain can become dislocated due to bending forces caused by stumps.

Cutlink has presented a low RPM solution based on rotating cone-shaped shears that cut 50-100 cm wide corridors between and around seedlings. In this study, the productivity of mechanized tending with Cutlink's device compared to manual tending was evaluated in spruce seedling stands in central Finland. The productivity, fuel consumption and quality of the seedling stand after the operation were measured. In early tending, the productivity of motor manual tending was notably better than when using the Cutlink device. Crucial factors for the competitiveness of a mechanized alternative include the annual working hours and finding suitable working areas for the machine. Additional work for the device and base machine can also be found in the clearing of forest road sides.
\end{abstract}

Keywords: seedling stands, mechanized tending, productivity

\section{Introduction}

In its National Bioeconomy Strategy, Finland aims to increase the annual output of the bioeconomy sector to 100 billion $€$ and create 100,000 new jobs by 2030 . The share of the forest based sector in the national bioeconomy output is 43 billion out of 65 billion $€$. Thus, to reach the ambitious targets, the goal for the annual cut from the Finnish forests should increase from 65 million $\mathrm{m}^{3}$ to 80 million $\mathrm{m}^{3}$ by 2030 (the Finnish Bioeconomy Strategy 2014). Although the annual growth has reached 107 million $\mathrm{m}^{3} \mathrm{y}^{-1}$, there are concerns for the sustainable availability of woody biomass for industry. For this reason, action is needed to increase the wood production on existing forest land.
According to forest inventory data, there is an urgent need for tending seedling stands on at least 700,000 ha and a need for 1 million ha in the next few years in Finland (Korhonen et al. 2017). Forest owners lose millions of euros every year due to neglected tendings. The motivation of forest owners to conduct precommercial silvicultural operations is low due to the high associated costs (Peltola 2014). The costs of tending and clearing operations after the regeneration of the stand have been especially increasing. In addition, the availability of labor can be a restricting factor due to high seasonality of silvicultural work.

Removing hardwoods and other competing vegetation from young stands increases the growth of the released trees and enhances the yield of commercial 
timber (Walfridsson 1976, Nilsson and Örlander 1999, Comeau et al. 2000, Jobidon 2000, Siipilehto 2001, Hytönen and Jylhä 2008, Fu et al. 2008, Boateng et al. 2009). However, in practice hardwoods are often removed too late to gain the most benefit from their removal (Uotila et al. 2012, Uotila and Saksa 2013). Abundantly, growing hardwoods create a need for early cleaning to control the competition arising from their growth, and in subsequent years pre-commercial thinning is also generally needed to control the overall stem density in a stand (Uotila 2016).

Early pre-commercial thinning (PCT), and ordinary PCT of seedling stands, includes cleaning the brush and thinning the stand to a suitable growth density. Early PCT means removing less valuable fast growing pioneering deciduous tree species that hamper the growth of the desired tree species. Ordinary PCT, is applied to adjust the density of the desired tree species for an optimal management (Uotila et al. 2012). This is done to ensure that the seedlings get enough light, space and nutrients to grow well. Tending the seedling stand at the right time increases the profitability of the first thinning. The timing and intensity of tending affect the yield and quality development of young stands as well as the timing and profitability of the first commercial thinning (Huuskonen and Hynynen 2006). In general, during the whole rotation, thinning is known to reduce the total yield, but the resulting increase in growing space accelerates growth of the tree diameter and volume, and enhances crown development (Assman 1970, Vuokila 1981). In young stands, early and intensive pre-commercial thinning accelerates the volume growth of the trees, and increases the yield of merchantable wood at the first commercial thinning stage. Due to the increased growing space, the branches grow thicker and longer, and crown recession slows down (Kellomäki and Tuimala 1981, Fahlvik et al. 2005).

The success or failure of young seedling stand management has long-term effects on stand development and subsequently on profitability. Light precommercial thinnings ( $>2500$ or even more than 4000 remaining trees per ha) are favorable in terms of stem quality development (Huuri et al. 1987, Varmola 1996, Agestam et al. 1998, Varmola and Salminen 2004), and for $\mathrm{CO}_{2}$ sequestration (Routa 2011). From the point of view of forest management profitability, however, light pre-commercial thinnings are less favorable. Carrying out light pre-commercial thinning may result in the need for another costly pre-commercial thinning, or early first commercial thinning with a small removal of merchantable wood and a negligible thinning income. Determining the need and proper timing for the tending of seedling stands has a large impact on the growth and dynamics of the tree stand, as well as on the profitability of the first commercial thinning (Huuskonen and Hynynen 2006, Uotila 2016).

Early thinning is recommended for Norway spruce stands when they reach a height of one meter (Luoranen et al. 2012). Later on, when the height is $3-5 \mathrm{~m}$, the stands are generally recommended to be pre-commercially thinned to a density of 1600-2200 stems ha ${ }^{-1}$ (Luoranen et al. 2012, Äijälä et al. 2014).

In the 2000s, several solutions for the mechanization of tending have been proposed. These are based on the use of a harvester or a forwarder as a base machine. Typically, light-weight base machines are favored to reduce the hourly cost of operations and the impacts on the remaining seedlings. However, there are challenges with the high speed of the cutting device, which increases the risk of damage to the head and the ignition of forest fires when the circular saw or chain hits stones. In addition, the chain can be dislocated due to forces caused by tree stumps. The productivity and the cost-efficiency of mechanized tending devices need to increase remarkably by developing the machines and adopting automation solutions to help operators (Strandström et al. 2009).

The aim of this study was to compare the productivity of mechanized tending with the Cutlink device to manual tending in spruce seedling stands in central Finland. The productivity, fuel consumption and quality of seedling stands after early pre-commercial thinning were measured.

\section{Materials and Methods}

\subsection{Field Experiment}

A field experiment consisting of carrying out early thinning was conducted in June 2018 at Tampere, in Finland $\left(61^{\circ} 43^{\prime} \mathrm{N}, 24^{\circ} 00^{\prime} \mathrm{E}\right)$, in planted Norway spruce stands with a variable mixture of broadleaved trees and raspberry bushes. Seedlings were planted in 2014, while the soil preparation method consisted of mounding and the average height of spruce seedlings was $85 \mathrm{~cm}$. The mean annual precipitation in this area is 600-700 $\mathrm{mm}$ and the mean annual temperature stands at $4-5^{\circ} \mathrm{C}$. The soil was classified either as a mineral soil or as swamped ground (2 plots), and the site fertility was classified according to Cajander's (1926) site type classification as a Myrtillus type (MT), which means fertile soil.

The size of the experimental area was 2.9 ha. The area was divided into 3 sections, and for each section, 2 blocks for motor-manual tending and 2 blocks for 

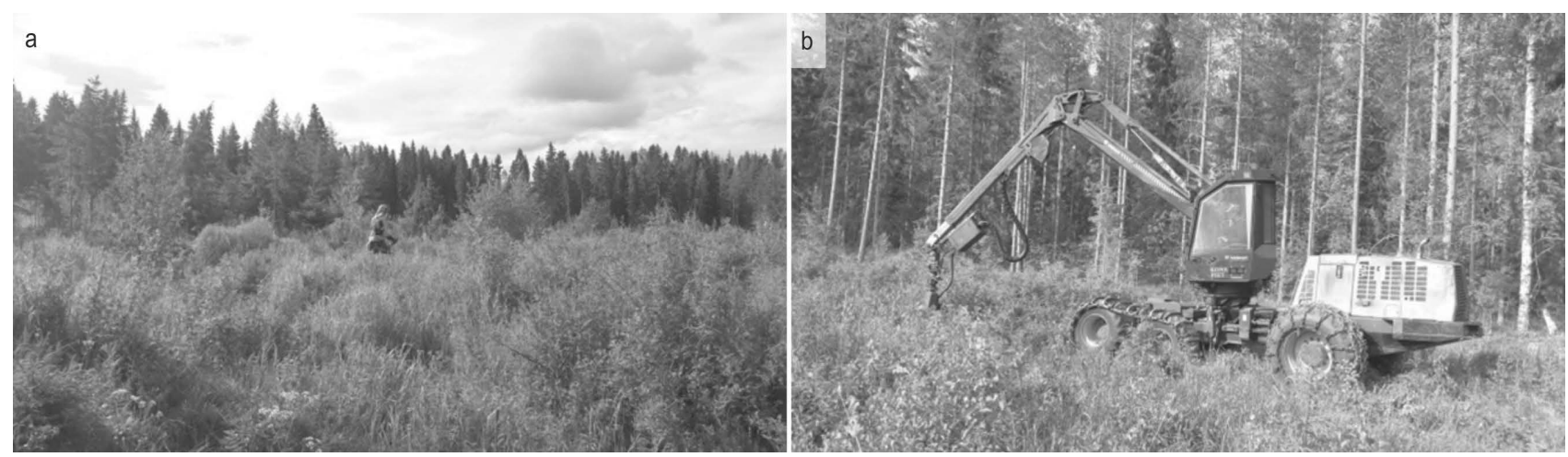

Fig. 1 Motor-manual tending (a) and mechanized tending (b) were compared in a field experiment

mechanized tending were established; in section 2 there were 3 blocks for mechanized tending. In each section, the blocks of mechanized and motor-manual tending were placed next to each other in order to reach the stand density of the blocks as close as possible. The block size was adapted for 30 min effective working time. Furthermore the terrain of blocks for motor-manual and mechanized tending were as similar as possible to make the work comparable (Fig. 1). The block areas varied between $475-3784 \mathrm{~m}^{2}$, with an average block size of $1050 \mathrm{~m}^{2}$. The experimental area was measured after cleaning using a systematic line survey method of 5-6 sample plots per block. In total 67 rectangular plots were established, 35 for mechanized tending, and 32 for motor-manual tending.

Crop trees in the main plots $\left(50 \mathrm{~m}^{2}, r=3.99 \mathrm{~m}\right)$ were evaluated by species and their mean heights were estimated. Trees that were not crop trees were considered for removal, but not removed. The number of removed trees was calculated from the subplots. The subplots $\left(3.14 \mathrm{~m}^{2}, r=1 \mathrm{~m}\right)$ were smaller than the main plots, but they were located at the same midpoint. The mean diameter and height of the stumps in the subplots were measured.

Motor-manual early cutting was made with a brush saw, and the logger had more than 25-years work experience. Mechanized early cutting was made with Cutlink device, and the base machine was a Valmet 901.3. The driver had more than 15 years of work experience with harvesters, but only 2-3 weeks with the Cutlink device. Fuel consumption of the machine was estimated when re-fueling the machine at the end of the experiment. Fuel consumption of the brush-saw was estimated when re-fueling the saw.

\subsection{The Cutlink Technology}

Using the Cutlink technology, stems are fed continuously to the blades by conical screws, and the

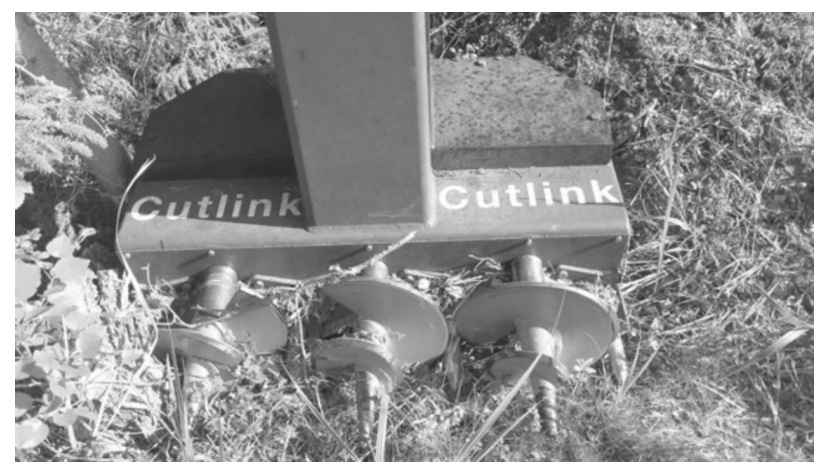

Fig. 2 Cutlink device based on rotating cone-shaped shears that cut $50-100 \mathrm{~cm}$ wide corridors between and around seedlings

work is not interrupted by unwanted matter hitting the blades. The stems are not crushed or ground by the screws, but they are cut as if by a rotating guillotine cutter as they move against the rear blade (Fig. 2). Cutlink has low rotation speed (300 rpm), so the screws do not throw splinters, stones or debris into the surroundings. The device is thus safe to use even near dwellings or in the vicinity of rocks, rubble, fences and other structures. The conical screw technology does not require a carrier with a high rotation speed, which saves fuel and reduces noise. The weight of the device is $330 \mathrm{~kg}$ and the cutting width is $105 \mathrm{~cm}$. The maximum cutting thickness at a single pass is $11 \mathrm{~cm}$. The minimum hydraulic output required is $60 \mathrm{l} / \mathrm{min} 180 \mathrm{bar}$ -100 1/min 280 bar.

\subsection{Data Analysis}

Field study material for time and motion studies was collected using a digital video camera (Nuutinen 2013). The operators' work was videotaped using a digital video camera recording from the operators' point of view. A small digital video camera was attached to the helmet on the operator's head. The Cutlink 
Table 1 Divisions of work phases used for the time-and motion study

\begin{tabular}{|c|c|c|}
\hline & Work phase & Definition \\
\hline \multirow{4}{*}{ 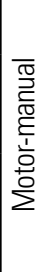 } & Clearing and moving & Simultaneous clearing and moving. Starts when the logger starts to move and clear and ends when the moving and clearing stops \\
\hline & Moving & $\begin{array}{l}\text { Includes moving to the non-merchantable trees without clearing. Starts when the clearing ends and the logger start to move } \\
\text { and end when clearing and moving begins }\end{array}$ \\
\hline & Organizational pause & E.g. Operator on the phone \\
\hline & Delay & E.g. Sharpening the felling roller \\
\hline \multirow{7}{*}{ 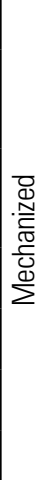 } & Clearing & Removal of nonmerchantable trees. Starts when the felling cut begins and ends when the felling cut stops \\
\hline & Cleaning the head & $\begin{array}{l}\text { Cleaning the felling head from felling waste. Starts when the felling cut stops and ends when the felling head is empty of } \\
\text { felling waste and the boom out or clearing work phases starts }\end{array}$ \\
\hline & Boom out & $\begin{array}{l}\text { Moving and positioning the felling head to start clearing. Starts when the boom begins to swing toward non-merchantable } \\
\text { trees and ends when the clearing begins }\end{array}$ \\
\hline & Moving forward & Begins when the harvester starts to move forward and ends when the harvester stops \\
\hline & Moving backward & Begins when the harvester starts to move backward and ends when the harvester stops \\
\hline & Organizational pause & E.g. Operator on the phone \\
\hline & Delay & E.g. Sharpening the felling roller \\
\hline
\end{tabular}

operator and motor-manual operator were filmed just as if the operators were in normal working situations without any special experimental arrangements. The time consumption of the work phases for both the motor-manual and mechanized tending was recorded, and the working time was divided into work elements (Table 1).

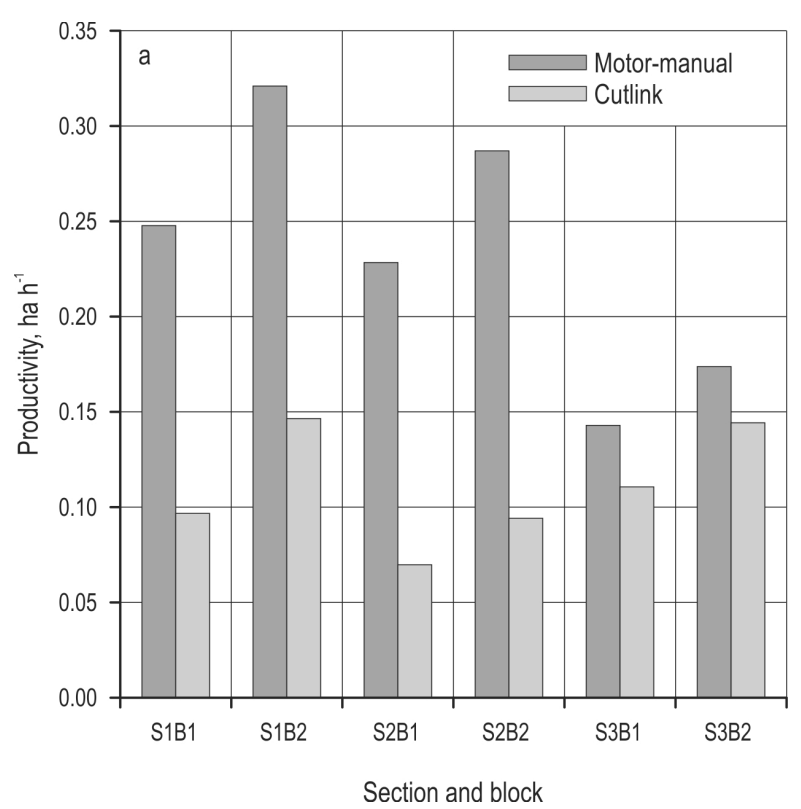

The time consumption of tending was measured for each section and the results were calculated as ha per hour. The stand density, the number of removed trees and number of trees left were calculated from subplots, and converted to seedlings per ha.

Statistical analyses were performed using IBM SPSS Statistics 25 . The significance level was 5\%

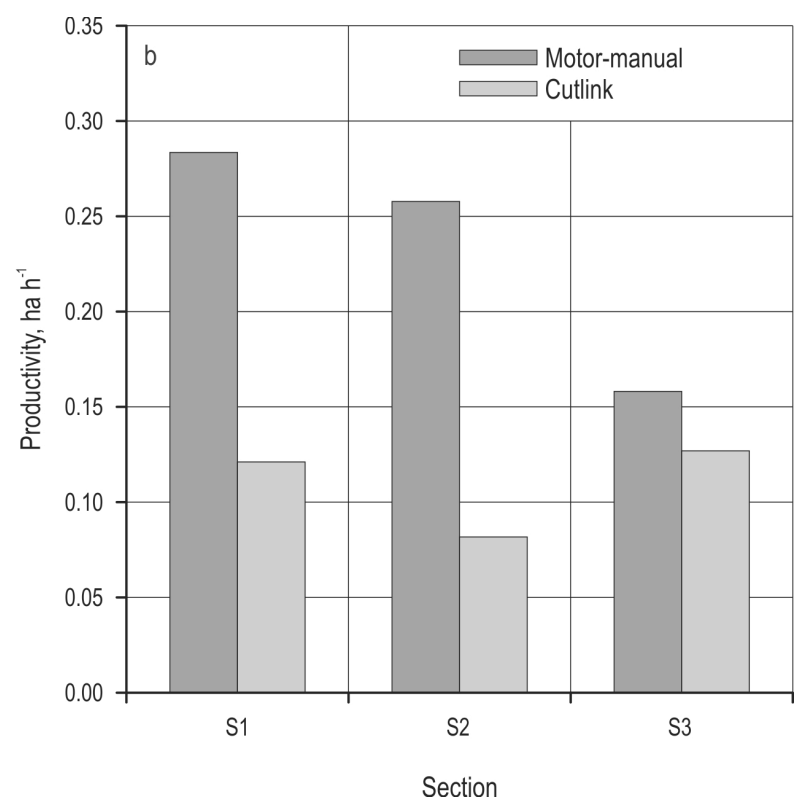

Fig. 3 Productivity $\left(\mathrm{ha}^{-1}\right.$ ) of motor-manual tending and Cutlink device in each block (a) and average of each section (b) 
$(p \leq 0.05)$ for all tests. Independent Samples $T$ test was executed for productivity, distribution of stand densities before tending (stand density), removal, remaining trees after operations- data to find out the differences between the methods.

\section{Results}

\subsection{Productivity}

The average productivity of the motor manual tending in sections 1 and 2 was the same, averaging 0.27 ha $^{-1}$, but the productivity in section 3 was $41 \%$ lower $\left(0.16 \mathrm{ha} \mathrm{h}^{-1}\right)$ compared to 1 and 2 (Fig. 3). The average productivity of the Cutlink device in sections 1 and 3 did not differ considerably $\left(0.12\right.$ and 0.13 ha $\left.^{-1}\right)$, respectively. The productivity of the Cutlink device in section 2 was about $33 \%$ lower $\left(0.08\right.$ ha h$\left.^{-1}\right)$ than in sections 1 and 3 (Fig. 3). The average productivity of motor-manual tending $\left(0.23 \mathrm{ha} \mathrm{h}^{-1}\right)$ was remarkably better than the productivity of Cutlink device $\left(0.11 \mathrm{ha} \mathrm{h}^{-1}\right)$ (Table 2).The difference was statistically significant $(p=0.001, t(11)=4.459)$.

In section 1 , at the beginning, the stand density varied between 20,700-49,700 seedlings per ha. Correspondingly, in section 2 and 3, the density was 17,400-

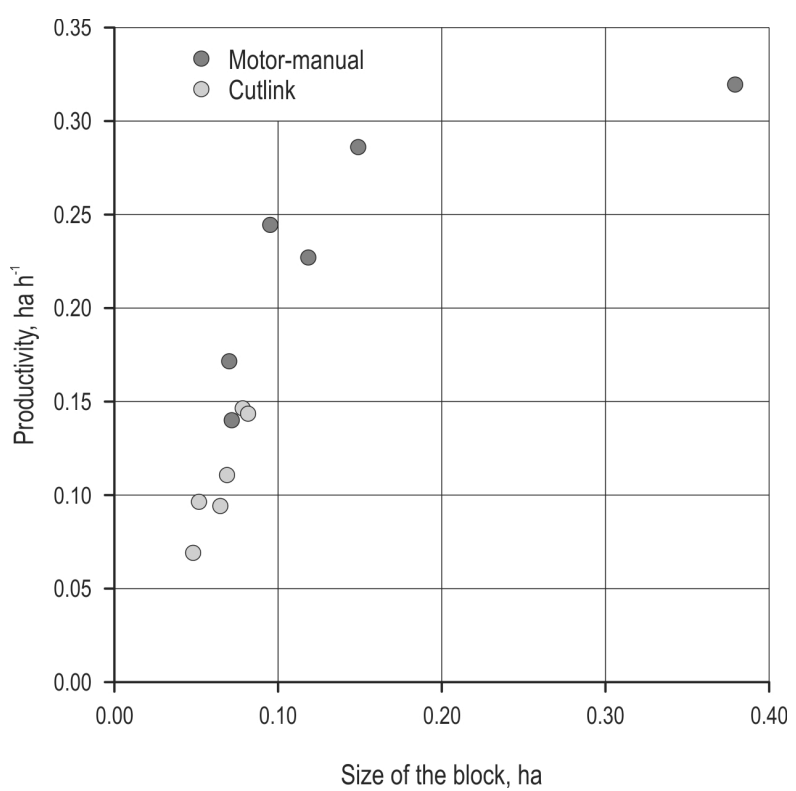

Fig. 4 The effect of block size (ha) on productivity of motor manual and Cutlink tending

38,700 and 31,600-54,300 seedlings per ha, respectively (Table 2). At the beginning, the stand density did not have an effect on the productivity of tending in this

Table 2 Productivity of tending, distribution of stand densities before tending (stand density), removal, remaining trees after operations, size of the experiment block in the motor manual and Cutlink experiments. Number of working locations and proportion of clearing in the Cutlink experiment

\begin{tabular}{|c|c|c|c|c|c|c|c|c|c|}
\hline \multicolumn{2}{|l|}{$\begin{array}{l}\text { Section } \\
\text { block }\end{array}$} & $\begin{array}{c}\text { Productivity } \\
\text { ha }^{-1}\end{array}$ & $\begin{array}{l}\text { Density } \\
\text { trees ha }^{-1}\end{array}$ & $\begin{array}{l}\text { Removal } \\
\text { trees ha }^{-1}\end{array}$ & $\begin{array}{l}\text { Remaining } \\
\text { trees } \\
\text { trees ha }^{-1}\end{array}$ & $\begin{array}{c}\text { Size of block } \\
\text { ha }\end{array}$ & $\begin{array}{l}\text { Number of } \\
\text { working } \\
\text { locations }\end{array}$ & $\begin{array}{l}\text { Proportion } \\
\text { of clearing } \\
\text { of } E_{0} h, \%\end{array}$ & $\begin{array}{l}\text { Proportion of } \\
\text { cleaning the } \\
\text { head of } E_{0} h, \%\end{array}$ \\
\hline S1B1M & \multirow{6}{*}{ 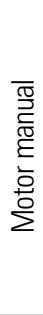 } & 0.25 & 38,254 & 33,121 & 5133 & 0.09 & - & - & - \\
\hline S1B2M & & 0.32 & 49,693 & 45,117 & 4576 & 0.38 & - & - & - \\
\hline S2B1M & & 0.23 & 18,277 & 14,862 & 3415 & 0.12 & - & - & - \\
\hline S2B2M & & 0.29 & 17,434 & 12,102 & 5332 & 0.15 & - & - & - \\
\hline S3B1M & & 0.14 & 54,336 & 47,134 & 7202 & 0.07 & - & - & - \\
\hline S3B2M & & 0.17 & 37,378 & 30,573 & 6804 & 0.07 & - & - & - \\
\hline \multicolumn{2}{|c|}{ On average } & 0.23 & 35,895 & 30,485 & 5410 & 0.15 & - & - & - \\
\hline S1B1C & \multirow{7}{*}{ 美 } & 0.10 & 32,396 & 13,376 & 19,021 & 0.05 & 11 & 85.7 & 5.5 \\
\hline S1B2C & & 0.15 & 20,735 & 8280 & 12,455 & 0.08 & 13 & 83.3 & 5.0 \\
\hline S2B1C & & 0.07 & 38,727 & 21,656 & 17,071 & 0.05 & 16 & 82.9 & 6.8 \\
\hline S2B2C & & 0.09 & 13,452 & 4459 & 8993 & 0.06 & 12 & 81.2 & 6.2 \\
\hline S2B3C & & 0.08 & 33,791 & 19,108 & 14,683 & 0.09 & - & - & - \\
\hline S3B1C & & 0.11 & 31,637 & 5096 & 26,541 & 0.07 & 17 & 82.5 & 5.1 \\
\hline S3B2C & & 0.14 & 43,738 & 15,287 & 28,451 & 0.08 & 17 & 82.5 & 4.1 \\
\hline \multicolumn{2}{|l|}{ On average } & 0.11 & 30,639 & 12,466 & 18,174 & 0.07 & - & - & - \\
\hline
\end{tabular}



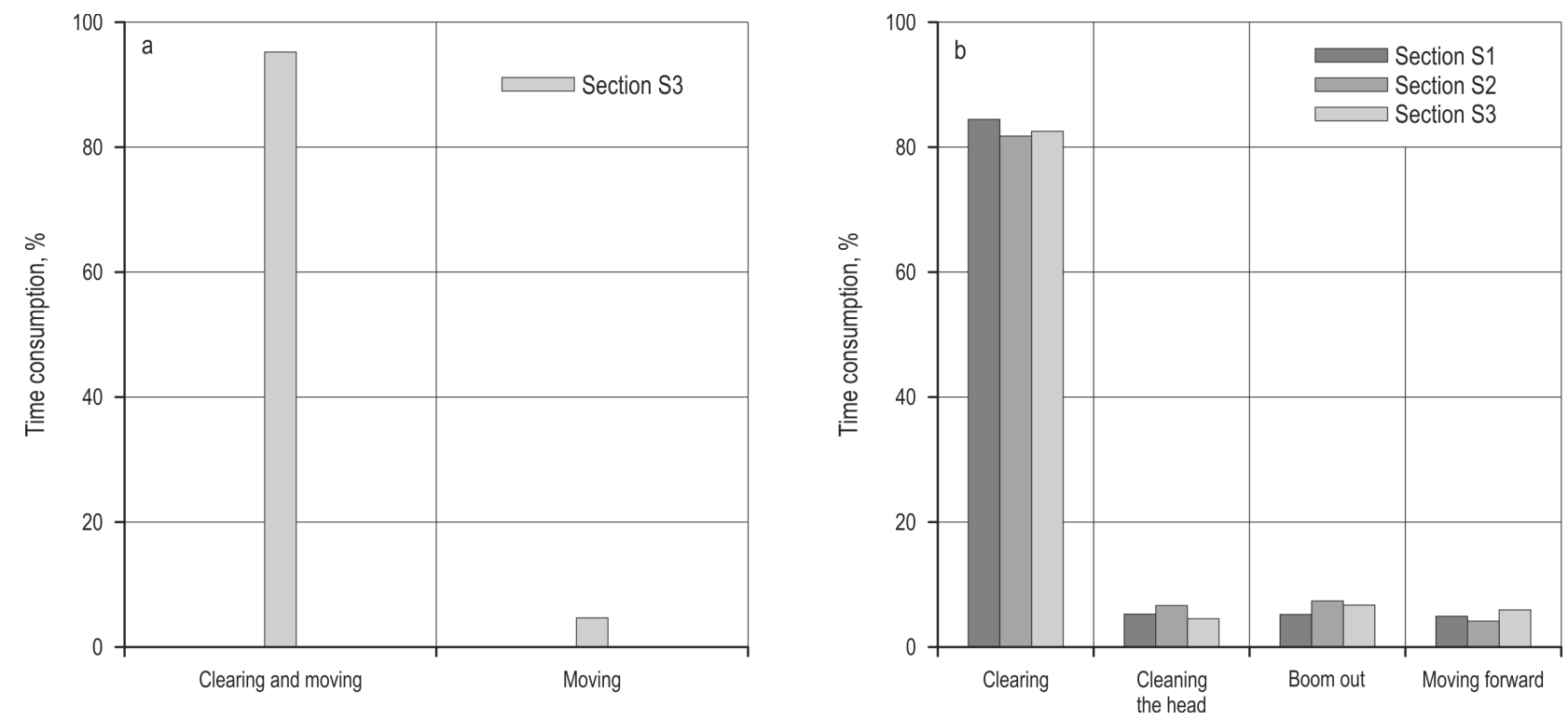

Fig. 5 Relative time consumption (\%) for the work phases (Table 1) for the motor-manual (a) and Cutlink-concept tending (b)

study. However, the highest productivity in motor manual tending was achieved in section 1, block 2, which was a very dense stand $(49,600$ seedlings per ha), and the removal was around 45,000 seedlings per ha. At the beginning of the experiment, the average density between motor-manual plots and Cutlink plots was not statistically significant $(p=0.48, t(11)=0.732)$

Cutlink achieved its highest productivity in section 1 , block 2 , but the density in this case was only 20,700 seedlings per ha, and the removal was around 8000 seedlings per ha.

The size of the blocks varied between $0.07-0.38$ ha for the motor manual tending and between $0.05-0.08$ ha for the Cutlink tending. The size of the block had an impact on the productivity; the bigger the block size, the better was the productivity (Fig. 4). For the Cutlink device, the highest removal of $51 \%$ was in section 2 , where the productivity was clearly the lowest. In sections 1 and 3, a higher productivity level was reached, wherein the removal proportion was significantly lower. In general, the proportion of work phase clearing the head increased significantly as the productivity decreased (Table 2, Fig. 3).

\subsection{Distribution of Effective Working Time}

Fig. 5 shows the recorded average time structure of the work phases (Table 1) for the effective work time $\left(\mathrm{E}_{0} \mathrm{~h}\right)$ for the studied Cutlink concept and motor manual tending. Manual tending was recorded only for section 3. In manual tending, the proportion of clearing including simultaneous moving was $95.5 \%$. The propor- tion of moving was $4.5 \%$. This work phase did not include other simultaneous functions. In manual tending, the logger's working sector, where he proceeded and cleared trees simultaneously, was 3-4 m wide. Unnecessary moving across treeless areas occurred rarely.

The average proportion of the clearing work phase to the effective work time $\left(\mathrm{E}_{0} \mathrm{~h}\right)$ was $83 \%$ for the Cutlink device. During the Cutlink operation, overlapping durations of simultaneous work phases did not occur. This means that clearing was not done during boom out and moving forward work phases that averaged 11.5\% of the $\mathrm{E}_{0} \mathrm{~h}$. The proportion of clearing work phase per block increased 2.2 percentage points as the productivity increased from 0.09 to $0.15 \mathrm{ha} \mathrm{h}^{-1}$ (Table 2). The productivity of the Cutlink concept increased from 0.08 to 0.13 ha $^{-1}$ (Fig. 3) as the proportion of the removal decreased from 51 to $27 \%$ (Fig. 5). Kariniemi (2006) has described the working location as follows: "The working location is an ideal area limited to the reach of the boom, within which it is possible to work as a single entity, provided that the operator is skilled enough «. The number of working locations per section increased from 12 to 16 as the proportion of the clearing work phase decreased from 84.5 to $82.6 \%$ (Table 2). At the same time the combined proportion of boom out and moving forward working phases of the $\mathrm{E}_{0} \mathrm{~h}$ increased from $10.2 \%$ to $12.7 \%$ (Fig. 6 ).

\subsection{Work Quality}

The removal varied between 12,000-47,000 (motormanual) and 4500-21,600 (Cutlink) and the average 

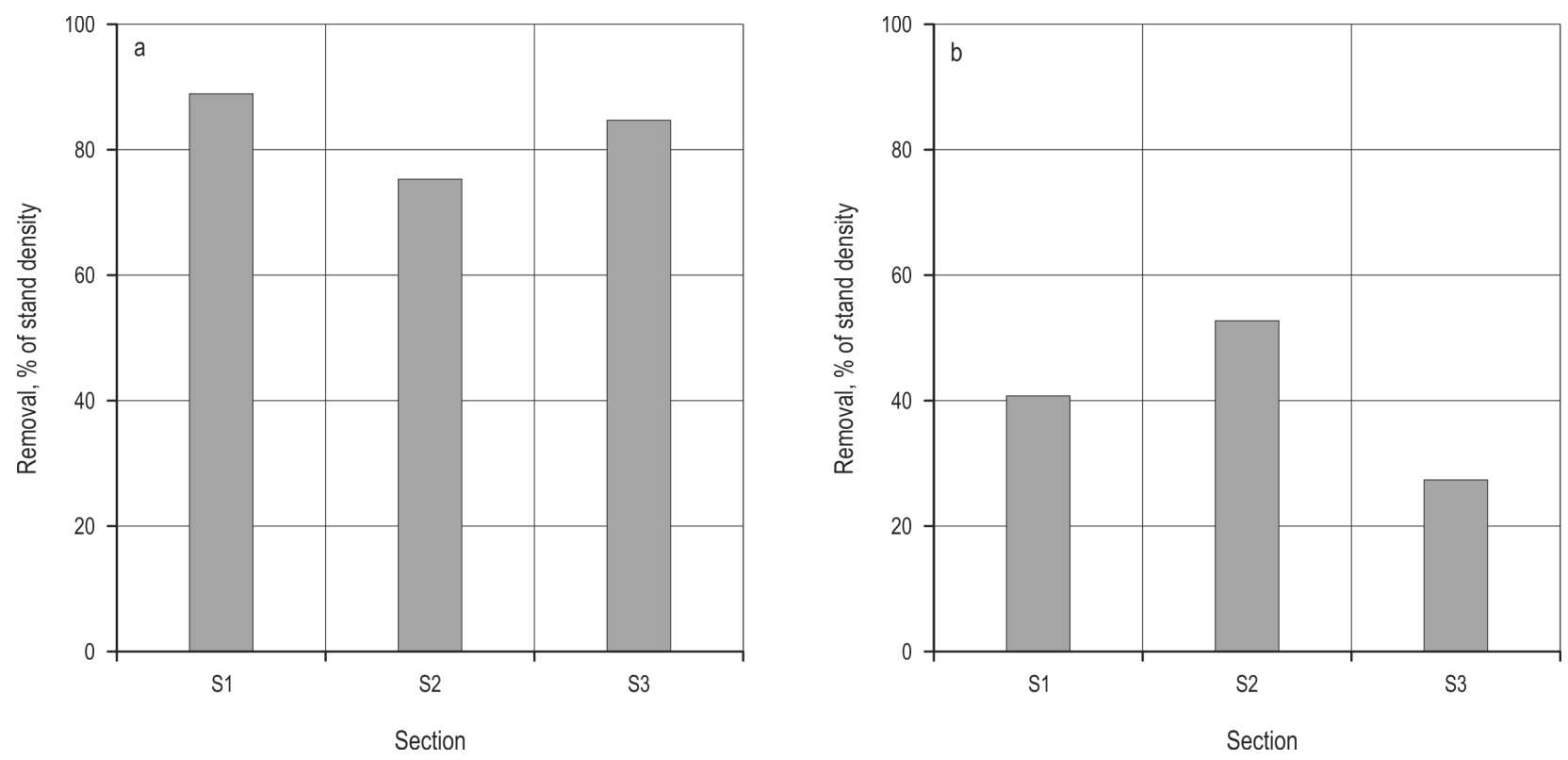

Fig. 6 Proportion of removal of stand density motor-manual tending (a) and Cutlink (b)

diameter of the removed seedlings were $8 \mathrm{~mm}$ (Table 2). The average number of seedlings left in the stand varied between 3400-7200 (motor-manual) and 900028,400 (Cutlink). In motor-manual tending the proportion of removal was remarkably higher than in the Cutlink tending. The proportion was in the range of $76-89 \%$ of the stand density and was thus at the same level in each section of motor manual tending areas (Fig. 6). The density of the remaining seedlings in the Cutlink blocks was the highest in section 3 , where the density was also the highest (38,000 seedling per ha) at the beginning. The removal was at the same level in sections 1 and 2 $\left(10,000\right.$ seedlings ha $\left.{ }^{-1}\right)$. In section 2 , the proportion of the removal of the stand density was $53 \%$, while for sections 1 and 2 the proportions were $41 \%$ and $27 \%$, respectively (Fig. 6). The removal in motor-manual plots was remarkably higher than in Cutlink plots, and the difference was statistically significant $(p=0.014$, $t(11)=2.92)$. Correspondingly, the amount of remaining trees was remarkably higher in Cutlink plots than in motor-manual plots, and the difference was statistically significant $(p=0.001, t(6.5)=4.619)$.

\subsection{Fuel Consumption}

The fuel consumption of the Cutlink was estimated when re-fueling the base machine at the end of the experiment. The fuel consumption for mechanized tending with the Cutlink machine was $1031 \mathrm{ha}^{-1}$. The fuel consumption of the brush-saw was estimated when re-fueling the saw, and the fuel consumption during the test was $41 \mathrm{ha}^{-1}$.

\section{Discussion}

We compared the productivity of mechanized tending with a Cutlink device to manual tending in spruce seedling stands in central Finland. Motor manual tending was noticeably faster and the quality of the work was better than with Cutlink. The average productivity of motor manual tending was $0.23 \mathrm{ha} \mathrm{h}^{-1}$ and with the Cutlink device it was $0.11 \mathrm{ha} \mathrm{h}^{-1}$. However, the test period was on average 35 minutes, and the work efficiency of motor manual work will certainly decrease after continuous work of several hours. We conducted all motor manual tests on the same day and observed that in the last section the difference was the smallest between motor manual tending and the Cutlink device. However, similar productivities of $0.08-0.37$ ha $^{-1}$ for early motor manual tending of spruce in the summer time have been reported (Koskinen 2013). For mechanized tending productivities of $0.05-0.2 \mathrm{ha} \mathrm{h}^{-1}$ in spruce and pine stands with bigger trees (average height of seedlings 2-4 $\mathrm{m}$ ) have been reported (Strandström et al. 2011, Hämäläinen et al. 2013). In our experiment, the size of the blocks was very small (0.05-0.38 ha), and we observed that, when the block size increased, the productivity of tending incereased. Koskinen (2013) has also reported similar results for motor manual tending. Several characteristics, like size of the removal trees, density, spatial distribution, forets type, terrain, season and skills of the logger, affect the productivity (Hämäläinen and Kaila 1983, Uusitalo 2003, Riikilä 2010, Uotila et al. 2014). In our experiment, the spatial distribution of the seedlings was not uniform, 
and it can be one of the reasons affecting productivity. However, the blocks to motor-manual and to Cutlink device were as uniform as possible. The working time was standardized in our study, the aim was to work around 30 minutes at a time, and one working session with both methods was around 60 minutes. This is the reason why the experiment plot sizes differ from each other in our study.

The conditions in the experimental stand were slippery, and the quality of the work of the Cutlink device was not very good; very small birch seedlings were difficult to cut with the device. The blades were sharped during the test, but the cutting of small birches was still very difficult. With Cutlink, the removal was smaller than the amount of remaining seedlings, so the quality of work was not acceptable in all blocks. In general, work quality of mechanized tending is lower than that of motor manual tending and damages have been reported to remaining trees (Rantala and Kautto 2011, Sandtröm et al. 2011).

The Cutlink operated using the maximum boom reach of $10 \mathrm{~m}$, and the distance between strip roads was $20 \mathrm{~m}$. When entering to the working location, the Cutlink operator first swung the clearing device to its maximum position to the front right of the machine and started to clear perpendicular to the strip road. The boom movement was not optimal for the removed trees because the clearing device was swung into treeless areas. The reason for this was that the base machine was too big to flexibly follow the removed trees. In our study, the productivity of the Cutlink device increased as the proportion of clearing work phase increased. Furthermore the productivity increased from 0.08 to $0.13 \mathrm{ha} \mathrm{h}^{-1}$ when the proportion of removal decreased from $51 \%$ to $27 \%$. These results indicate that, in order to increase the work efficiency and quality, important development target is the semi-automatic boom tip control (Löfgren 2009) to maximize the flexible movements of felling device during moving.

In manual tending, the logger's working sector, where he proceeded and cleared trees simultaneously, was 3-4 m wide. Unnecessary moving across the treeless areas rarely occurred. This flexible working technique explains why the logger efficiently and flexibly reached all the seedlings to be removed. The proportion of removal was on average $81 \%$, while for Cutlink it was only $39 \%$. The increase in the productivity did not decrease the percentage of removal in contrast to the Cutlink. The results indicate that for increasing Cutlink productivity calls for minimizing the number of working locations.

Ovaskainen (2009) developed a model describing factors influencing productivity in harvester work.
The model can also be adapted for our study. There were significant productivity differences between the sections of both tending methods (Cutlink and manual tending). Most probably the differences can be explained by the heterogeneity of the cutting environment, which is the most common challenge in forestry work studies. In our study, these factors were the density, size and spatial position of trees.

In this study, the base machine was a Valmet 901.3. In tending operations, the base machine size does not affect productivity of operations much, but the base machine does affect the cost-efficiency (Hämäläinen et al. 2013). Light and cheap base machines can be almost competitive with motor manual tending in suitable circumstances (Strandström et al. 2011). Fuel consumptions of 45-180 1 ha $^{-1}$ have been reported for mechanized tending (Strandström et al. 2011, Hämäläinen et al. 2013), and in this study the fuel consumption was $1031 \mathrm{ha}^{-1}$.

\section{Conclusions}

In our study, the development stage of the stand was too early for the Cutlink device, and our aim is to continue testing with a pre-commercial tending stand. Our study showed that the clearing accuracy of rotating shears in early tending of young stands of high densities was inadequate. In the study of Hämäläinen et al. (2013), it was observed that new machine options and thinning methods combined to operator-supporting camera systems have potential to improve the cost competitiveness and work quality of mechanization in pre-commercial thinning. Based on these results it can be assumed that the potential targets for Cutlink felling device working method and technique are precommercial thinnings with strong broad-leaved mixture. In these stands the tireless mechaniztion could bring the best possible surplus value.

However, the Cutlink device was found to be very reliable and its technical availability was exceptionally good considering its development stage. There were no interruptions during the tests. The availability of labor can be a restricting factor due to the high seasonality of silvicultural works (Pöyry 2004), new solutions are needed. The share of mechanized tending will increase in the future; the challenge is to improve the productivity bringing it up to a cost-efficient level. Possible solutions could include automation, sensor technology and machine vision. In addition, the selection of the right stands and training of operators are crucial for improving mechanization. Furthermore, working methods for mechanized tending should be developed; e.g. harvesting development in first thin- 
nings: multi-tree handling (Belbo 2011) and thinning methods (Bergström 2009). A new method is silver leaf fungus (Chondrostereum purpureum) treatment, which prevents the pruning of deciduous trees. Combining fungus treatment with mechanization improves the cost efficiency of the operation (Saarinen 2015).

In practice, we need to achieve a level, where machines are faster and more cost effective compared to motor-manual work. Mechanizing the silvicultural work improves the safety at work and decreases the physical stress of workers. In addition, the operation culture should be changed to favor more mechanization in the early phases of forest development.

\section{Acknowledgments}

This work was supported by the Bio Based Industries Joint Undertaking under the European Union's Horizon 2020 research and innovation program, TECH4EFFECT - Techniques and Technologies for Effective Wood Procurement - project, (grant number 720757) and the Strategic Research Council of Academy of Finland, FORBIO - Sustainable, climate-neutral and resource-efficient forest-based bioeconomy - project (grant number 314224). The authors gratefully acknowledge Veli-Matti Saarinen, Kari Kautto, Petteri Pieti and Jani Hanhisuo for the field experiment planning and implementing the work.

\section{References}

Agestam, E., Ekö, P.-M., Johansson, U., 1998: Timber quality and volume growth in naturally regenerated and planted Scots pine stands in S.W. Sweden. Studia Forestalia Suecica 204: $17 \mathrm{p}$.

Assmann, E., 1970: The principles of forest yield study Studies in the organic production, structure, increment and yield of forest stands. Pergamon Press. Oxford, $506 \mathrm{p}$.

Äijälä, O., Koistinen, A., Sved, J., Vanhatalo, K., Väisänen, P., (eds) 2014: Hyvän metsänhoidon suositukset (Best practices for sustainable forest management). Metsätalouden kehittämiskeskus Tapion julkaisuja, $180 \mathrm{p}$.

Belbo, H., 2011: Efficiency of accumulating felling heads and harvesting heads in mechanized thinning of small diameter trees. Linnaeus University Dissertations No. 66/2011. School of Engineering, $42 \mathrm{p}$.

Bergström, D., 2009: Techniques and systems for boom corridor thinning in young dense forests. Swedish University of Agricultural Sciences, Faculty of Forest Sciences. No. 2009:87, 53 p.

Boateng, J.O., Heineman, J.L., Bedford, L., Harper, G.J., Linnel Nemec, A.F. 2009: Long-term effects of site preparation and postplanting vegetation control on Picea glauca survival, growth and predicted yield in boreal British Columbia. Scan- dinavian Journal of Forest Research 24(2): 111-129. https:// doi.org/10.1080/02827580902759685

Cajander, A.K., 1926: The theory of forest types. Acta Forestalia Fennica 29: 1-108.

Comeau, P.G., Biring, B.S., Harper, G.J., 2000: Effectiveness of repeated manual cutting and glyphosate for release of Engelmann Spruce from mixed-shrub herb vegetation. Western Journal of Applied Forestry 15(3): 154-162. https:// doi.org/10.1093/wjaf/15.3.154

Fahlvik, N., Ekö, P.-M., Pettersson, N., 2005: Influence of precommercial thinning grade on branch diameter and crown ratio in Pinus sylvestris in southern Sweden. Scandinavian Journal of Forest Research 20(3): 243-251. https://doi. org/10.1080/02827580510008266

Fu, S., Chen, H.Y.H., Bell, F.W., Sharma, M., Delaney, J.R., Peterson, G., 2008: Effects of timing of glyphosate application on jack pine, black spruce, and white spruce plantations in northern Manitoba. The Forestry Chronicle 84: 37-45.

Finnish Bioeconomy Strategy - Sustainable growth from Bioeconomy, 2014: Edita Prima Ltd, 17 p.

Hämäläinen, J., Kaila, S., 1983: Taimikon perkauksen ja harvennuksen sekä uudistusalan raivauksen ajanmenekkisuhteet. Metsätehon katsaus 16/1983.

Hämäläinen, J., Strandström, M., Saarinen, V-M., Hynynen, J., Saksa, T., Hyyti, H., 2013: Koneellisen taimikonhoidon kustannustehokkuuden parantaminen. Metsätehon raportti 228, $27 \mathrm{p}$.

Huuri, O., Lähde, E., Huuri, L., 1987: Tiheyden vaikutus nuoren istutusmännikön laatuun ja tuotokseen. Folia Forestalia 685, $48 \mathrm{p}$.

Huuskonen, S., Hynynen, J., 2006: Timing and intensity of precommercial thinning and theireffects on the first commercial thinning in Scots pine stands. Silva Fennica 40(4): 645-662. https://doi.org/10.14214/sf.320

Hytönen, J., Jylhä, P., 2008: Fifteen-year response of weed control intensity and seedling type on Norway spruce survival and growth on arable land. Silva Fennica 42(3): 355368. https://doi.org/10.14214/sf.242

Jobidon, R., 2000: Density-dependent effects of northern hardwood competition on selected environmental resources and young white spruce (Picea glauca) plantation growth, mineral nutrition, and stand structural development - a 5-year study. Forest Ecology and Management 130(1): 77-97. https://doi.org/10.1016/S0378-1127(99)00176-0

Kariniemi, A., 2006: Kuljettajakeskeinen hakkuukonetyönmalli - työn suorituksen kognitiivinen tarkastelu. Helsingin yliopiston Metsävarojen käytön laitoksen julkaisuja 38, 126 p.

Kellomäki, S., Tuimala, A., 1981: Puuston tiheyden vaikutus puiden oksikkuuteen taimikko- ja riukuvaiheen männiköissä. Folia Forestalia 478. 27 p.

Korhonen, K.T., 2016: National forest inventories: assessment of wood availability and use: Finland. In: Vidal, C., Alberdi, I., Hernandez, L., Redmond, J.J. (eds.), National for- 
est inventories: assessment of wood availability and use. Springer, Berlin, 369-384.

Korhonen, K.T., Ihalainen, A., Ahola, A., Heikkinen, J., Henttonen, H.M., Hotanen, J.-P., Nevalainen, S., Pitkänen, J., Strandström, M., ja Viiri, H., 2017: Suomen metsät 2009-2013 ja niiden kehitys 1921-2013. Luonnonvara- ja biotalouden tutkimus 59/2017. Luonnonvarakeskus, Helsinki. 86 p.

Koskinen, H., 2013: Varhaisperkauksen työlajin ja ajankohdan vaikutus taimikonhoidon työajanmenekkiin ja uudelleen vesomiseen. University of Eastern Finland, Faculty of Science and Forestry, School of Forest Sciences, master's thesis in Forest Science specialization Forest Technology, $56 \mathrm{p}$.

Luoranen, J., Saksa, T., Uotila, K., 2012: Metsänuudistaminen. Metsäkustannus Oy, Hämeenlinna. 150 p.

Löfgren, B., 2009: Kinematic control of redundant knuckle booms with automatic path-following functions. Doctoral thesis in machine design. Department of Machine Design, Royal Institute of Technology. Stockholm, 159 p.

Nilsson, U., Örlander, G., 1999: Water uptake by planted picea abies in relation to competing field vegetation and seedling rooting depth on two grass-dominated sites in southern Sweden. Scandinavian Journal of Forest Research 14: 312-319.

Nuutinen, Y., 2013: Possibilities to use automatic and manual timing in time studies on harvester operations. University of Eastern Finland. Faculty of Science and Forestry. Dissertationes Forestales 156, 68 p.

Ovaskainen, H., 2009: Timber harvester operators' working technique in first thinning and the importance of cognitive abilities on work productivity. Doctoral thesis. University of Eastern Finland. Dissertationes Forestales 79, 62 p.

Peltola, A. (ed.), 2014: Finnish Statistical Yearbook of Forestry. Finnish Forest Research Institute. Tammerprint $\mathrm{Oy}$, Tampere, $428 \mathrm{p}$.

Pöyry Consulting 2004:Työvoiman saatavuus metsätaloudessa. Final report, 83 p.

Rantala, J., Kautto, K., 2011: Koneellinen kitkentä taimikon varhaisperkauksessa - työajanmenekki, kustannukset ja työjäljen laatu. Metsätieteen aikakauskirja 1/2011: 3-12.

Riikilä, M., 2010: Taimikonhoito. Helsinki. Metsäkustannus Oy, $85 \mathrm{p}$.

Routa, J., 2011: Effects of forest management on sustainability of integrated timber and energy wood production-scenario analysis based on ecosystem model simulations. Dissertationes Forestales 123, 31 p. +4 articles.
Saarinen, V-M., 2015: Yhden taimikonhoidon taktiikkaan biologisella vesakontorjunnalla. Luke taimiuutiset 4/2015.

Siipilehto, J., 2001: Effect of weed control with fibre mulches and herbicides on the initial development of spruce, birch and aspen seedlings on abandoned farmland. Silva Fennica 35(4): 403-414. https://doi.org/10.14214/sf.577

Strandströn, M., Hämäläinen, J., Pajuoja, H., 2009: Metsänhoidon koneellistaminen. Metsätehon raportti 206, 47 p.

Strandström, M., Saarinen, V.-M., Hallongren, H., Hämäläinen, J., Poikela, A., Rantala, J., 2011: Koneellisen istutuksen ja taimikonhoidon kilpailukyky. Metsätehon raportti 218, 29 p.

Uotila, K., Rantala, J., Saksa, T., 2011: Kustannustehokas ja kannattava metsänuudistamisketju. Metsätieteen aikakauskirja 2011(1) :35-38.

Uotila, K., Rantala, J., Saksa, T., 2012: Estimating the need for early cleaning in Norway spruce plantations in Finland. Silva Fennica 46(5): 683-693. https://doi.org/10.14214/sf.919

Uotila, K., Saksa, T., 2013: Effects of early cleaning on young Picea abies stands. Scandinavian Journal of Forest Research 29(2): 111-119. https://doi.org/10.1080/02827581.2013.869349

Uotila, K. Saksa, T., Rantala, J., Kiljunen, N., 2014: Labour consumption models applied to motor-manual pre-commercial thinning in Finland. Silva Fennica 48 (2): article id 982. https://doi.org/10.14214/sf.982

Uotila, K., 2016: Optimization of early cleaning and precommercial thinning methods in juvenile stand management of Norway spruce stands. Dissertationes Forestales 231, Department of Forest Sciences Faculty of Agriculture and Forestry, University of Helsinki.

Uusitalo, J., 2003: Metsäteknologian perusteet. Karisto Oy, Hämeenlinna. $230 \mathrm{p}$.

Varmola, M., 1996: Nuorten viljelymännniköiden tuotos ja laatu. Abstaract: Yield and quality of young Scots pine cultivation. Metsäntutkimuslaitoksen tiedonantoja 585. 70 p. + 6 appendices.

Varmola, M., Salminen, H., 2004: Timing and intensity of precommercial thinning in Pinus sylvestris stands. Scandinavian Journal of Forest Research 19(2): 142-151. https:// doi.org/10.1080/02827580310019545

Vuokila, Y., 1981: Nuoren männikön kasvureaktio ensiharvennuksen jälkeen. Summary: The growth reaction of young pine stands to the first commercial thinning. Folia Forestalia 468: $13 \mathrm{p}$.

Walfridsson, E., 1976: Lövets konkurrens i barrkulturen. Skogen 63: 631-633.

(C) 2019 by the authors. Submitted for possible open access publication under the terms and conditions of the Creative Commons Attribution (CC BY) license (http://creativecommons.org/licenses/by/4.0/). 
Authors' addresses:

Johanna Routa, $\mathrm{PhD}$ *

e-mail: johanna.routa@luke.fi

Yrjö Nuutinen, PhD

e-mail: yrjo.nuutinen@luke.fi

Prof. Antti Asikainen, PhD

e-mail: antti.asikainen@luke.fi

Natural Resources Institute Finland, Luke

Production systems

Forest technology and logistics

Yliopistokatu 6B

80100 Joensuu

Received: January 14, 2019

FINLAND

Accepted: June 6, 2019

* Corresponding author 